\title{
Author's approach to the formation of an innovative system of the municipal property management
}

\author{
Vyacheslav Prigozhin ${ }^{1, *}$ \\ ${ }^{1}$ Irkutsk National Research Technical University, 664074, Lermontova str., 83, Irkutsk, Russia
}

\begin{abstract}
Municipal property is one of the components of the economic basis of local self-government, and an important factor of the sustainable social and economic development of the city territory. The population feels and evaluates the results of the municipal property management by how its vital needs and interests are satisfied. This is to these needs and interests that municipal property is to serve that indicates its special role and causes the necessity to develop innovative approaches to the system of the municipal property management. Lack of attention of local authorities to this problem is a reason of social conflicts and a deficit of local budgets. Therefore, the management municipal property based on innovative approaches is an urgent task. To solve these issues, the author proposes, firstly, the mechanism for the formation of an innovative approach to the management system of municipal property. Secondly, he suggests a method that allows increasing efficiency of the municipal property management. The proposed mechanisms allow taking into account modern priorities of the municipal development, increasing entrepreneurial activity on the real estate market of municipalities, improving the quality of the municipal authorities' management, and rationally using the existing municipal property objects.
\end{abstract}

\section{Introduction}

In the conditions of constant search for sources of replenishment of local budgets, taking into account the role and importance of municipal property in the development of municipalities, municipal authorities need to search for new innovative methods and forms of management. Their absence leads to the fact that the state of the majority of the municipal property objects is unsatisfactory, since the problems of creating the necessary infrastructure, the development of the street and road network and transport services, urban construction and improvement, attracting investments and innovations in the development of municipal property are solved haphazardly and unsystematically [9].

The study of the global experience [1] shows that only the application of an innovative approach to the management of municipal property can significantly improve its effectiveness in the interests of the municipality. In particular, management innovations in

${ }^{*}$ Corresponding author: prigozhins@ mail.ru 
real estate have become indicators of the achievement of reforms in the advanced economies, such as the United States, Britain, Canada, the Netherlands, Sweden and New Zealand.

To solve these problems in our country, is, first of all, needed active implementation of new innovative approaches to the system of municipal property management $[4,16]$.

\section{Approaches to the formation of the innovative management system for municipal property}

In the 21 st century, the improving knowledge on property management is quite relevant as the level and quality of life of the population largely depends on how effectively municipal authorities perform the functions of the property management.

The sense of the process of implementation of the management functions by local governments is in establishing certain rules and conditions for owning, using and disposing of management objects. The greatest effect of the implementation of these rules is achieved when the administrative impact on the objects is systemic, that is, it is associated with a set of measures that form a control system.

The study of the experience of the Russian Federation regions [13, 18], and the analysis of works and publications on the management of municipal property and innovations [3,5], showed that at present municipal authorities do not demonstrate any innovative approach to the management of municipal property as a system.

This conclusion allowed the author proposing an approach in which the management of municipal property is viewed not as an activity for controlling individual objects but as a system for managing municipal property, the functioning of which is subordinated to the tasks of organizing a modern life support system that meets the requirements of the contemporary innovative market economy of the municipality.

Such logic of the presentation of an innovative approach to the management system of municipal property is based on the assumption that this system should have a feedback, and is to be built on the following principles: first, the primary goals of the municipality development are formed, and then the goals and tasks of the municipal property management are developed as a strategic resource for solving social and economic problems.

An innovative approach involves an interaction of elements of the internal environment of the system with elements of the external environment.

At the same time, it should be noted that the external environment and its constantly changing conditions affect all interacting elements in the municipal property management system, having an impact on both achieving the planned management results and the development goals of the municipality as a whole.

An innovative approach presupposes the existence of an effective system of local selfgovernment. It is possible through the certification of the activities of municipal authorities on quality management models that will promote for the following: improving the level and quality of life of the population; using it as an instrument for introducing innovations and investments in the economy of the municipality; making administrative work more effective; increasing the level of satisfaction of the society with the results of municipal property management; reducing administrative costs of the management system, etc.

In connection with a special role of municipal property as an asset that generates income, and also carries a social burden, the process of the municipal property management is specific and can be presented as a scheme on the Figure 1. 


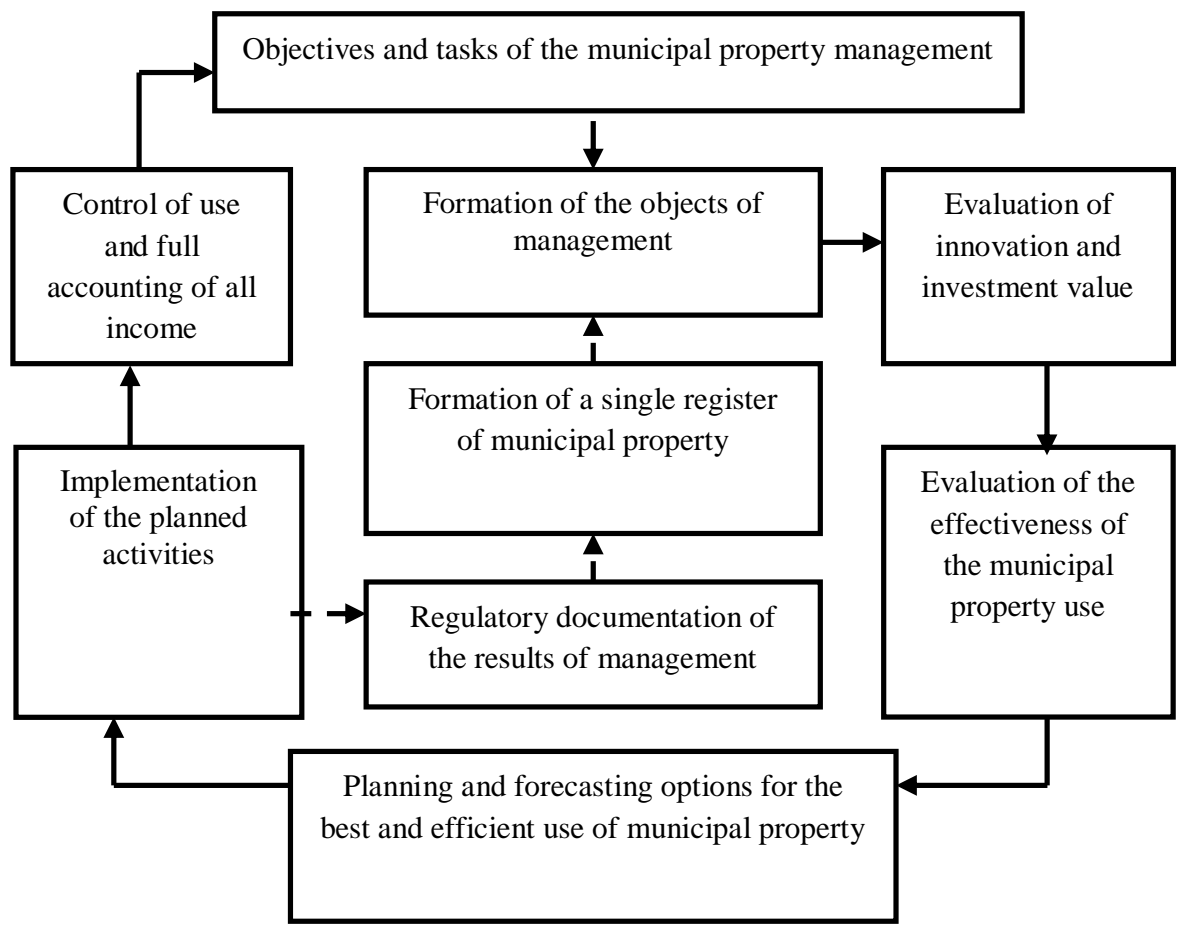

Fig. 1. Innovative approach to the process of the municipal property management.

The units and links shown on the Figure 1, make it possible to clarify the main role of the management objectives and tasks (inputs of the municipal property management system) dictated by the objectives and tasks of the municipality's development.

The next structural unit, which receives these objectives and tasks, is the unit for the formation of management objects, which is formed on the basis of a single register of municipal property.

The presented logical chain "performance evaluation - planning and forecasting implementation - control" corresponds to the traditional construction of the functional management systems. The outputs from the "control" unit are the feedback of the main contour of the municipal property management system and serve to inform the subjects of management whether or not the results of managing the objectives and tasks of the municipal property management are achieved. The principal moment for the municipal property management system is that the outputs of the "implementation" block have internal feedback.

The feedback information in the management system systemizes the unit of "regulatory documentation of management results". This will allow the subjects of management, as far as the solution of the assigned tasks is reached, sending information for adding and supplementing the composition of the database on municipal property.

Taking into account the aforesaid, it can be stated that the proposed innovative approach to the municipal property management system is the most acceptable way of realizing the functions of the municipal entity as an owner.

A competent and precise implementation of the innovative approach to the management system of municipal property will improve the efficiency of the municipal property use, taking into account the satisfaction of the interests of the entire local community and ensure sustainable development of the municipality. 


\section{The method of municipal property management with zoning of the municipality into functional zones}

The priority tasks of local governments in the field of the municipal property management are the following: using and developing municipal property for solving social and economic problems of the population of the municipality; increasing well-being and living standards of the population; creating favorable environment for comfortable living; and attracting investments for the innovative development of the municipality.

To solve this problem, we propose a method for managing municipal property, the implementation mechanism of which involves the successive passage of a number of hierarchically subordinate levels consisting of nine stages.

The first level is a definition of the city development strategy as a whole, in the framework of which municipal property is considered as one of the necessary resources.

At the first stage, in order to implement such a strategy, local governments should make the following: to determine the objectives of management; to identify the tasks that need to be solved to achieve these objectives; and to determine the means by which the chosen strategy will be achieved.

The result of the first level will be constituted in the decision of local authorities on what kind of city they would like to see: administrative, commercial, transport, cultural and educational, industrial, etc. After this, the second level is implemented.

The second level is a definition of strategy for the development of a territorial district. For that, the city's territory is divided into territorial districts.

At the second stage, the territorial development strategy is determined for the territorial district. The strategy for the development of the territorial district is determined on the basis of the master plan for city development.

At the third stage, the objectives of the territorial district development are determined based on the master plan for the development of the city.

At the fourth stage, zoning on functional zones is carried out in accordance with the development objectives of the territorial district. The purpose of this urban zoning is to optimize the use of the urban area, ensure comfortable living of the city residents, and create an up-to-date social, transport and engineering infrastructure. The formation of functional zones is carried out in accordance with the legislation of the Russian Federation.

For each functional zone, the need for the municipal property objects and the necessary resources is determined.

At the fifth stage, the strengths and weaknesses of the territorial district are identified in accordance with the zoning carried out. At this stage, a critical analysis of the current status of the functional zone is executed, and the development potential is determined. After that, the third level is realized.

The third level is the final one, and represents the choice of the form of management of a specific object of municipal property falling into a certain functional zone.

At the sixth stage, the real estate market is analyzed. To do it, there is a need to constantly monitor the market in two directions: the assessment of the state and prospects for the market development (analysis of market opportunities), and the assessment of the location of a potential real estate object (analysis of the potential of the location).

At the seventh stage, the objectives of managing the object of municipal property are determined based on the development strategy of the functional zone. The objectives of managing the object of municipal property can be the following: financial and economic; innovation and investment development, and socio-cultural.

At the eighth stage, we determine the possible form of managing the object of municipal property based on the chosen management objective. 
For financial and economic, and innovation and investment objectives, the decision to choose the form of management for each specific object of municipal property should take into account the following: the level of physical and moral depreciation; the need for capital investments; the payback period of investments; and the ratio of profitability and costs of maintenance.

At the same time, the following incomes can act as revenues from the effective use of the forms of municipal property management:

1) In case of municipalization: the revenues from the operation of the facility (net of operating costs), as well as the proceeds from the sale of the object after the expiration of the calculation period.

2) In case of the trust management: rental income (net of the management company's remuneration and operating costs) by years, the selling price of the asset after the expiry of the term of trust management.

3) When renting: rent by year (net of operating costs), the selling price of the property at the end of the lease term, and possibly (long-term lease) the value of long-term lease rights.

4) During privatization: the selling price of the object (cash receipts at the present time).

5) For security: the amount of the loan (arrives at the present time), the proceeds from the operation of the facility (net of operating costs and debt servicing costs), the selling price of the facility after the forecast period.

6) In liquidation: the market value of the land plot, minus cost of the demolition of improvements.

7) At the development: rent on years (minus expenses for changing the facility's profile), the selling price of the object after the term of rent, and the cost of the right of long-term rent that is also possible (at long-term rent).

8) When making a share: the share of income from the operation of the facility (minus the share of operating costs), and the selling price of the object after the expiration of the forecast period.

9) At the concession: the proceeds from the operation of the facility (minus the management company's remuneration and operating costs), and the selling price of the object after the expiration of the concession contract.

For socio-cultural objectives, the decision option for choosing the form of management for each object can be based on the following criteria: social significance; the needs of the city in such facilities in accordance with the recommended standards, and others.

At the ninth stage, control over the use of municipal property is exercised.

The control procedure includes measures and actions aimed at monitoring the current state of municipal property, the correctness and legality of their use, and decision-making on the unfair use of municipal property.

The results of the monitoring will be used in making the decision, which may be as follows:

1. Termination of the contract for the use of the object of municipal property due to illegality or inefficiency of use.

2. Review of the terms of the contract.

3. Continuation of work under the same conditions.

4. Change of the form of management.

The proposed methodology for the municipal property management will improve the efficiency of the municipal ownership use by local authorities. At the same time, the cumulative effect for the municipality of implementing this technique can be viewed as a combination of the following effects:

1) New jobs and higher living standards (social effect);

2) Maximization of income from municipal property (economic effect);

3) Increase in revenues to the budgets of all levels (budgetary effect); 
4) Ensuring environmental safety of the territory of the municipality and the region (environmental effect).

Thus, the introduction of the proposed author's innovative approach and methodology will make it possible to effectively and rationally use municipal property, to choose the form of management of a specific object of municipal property, based on its usefulness for innovative development of the city, to influence the development of the real estate market, and to extract the maximum benefit and profit from the objects of municipal property, directing it to improving the level and quality of life of the population.

\section{References}

1. S. Azasu, K. Gibler, Journal of Real Estate Literature, 24, 287-308 (2016)

2. M. Fritsch, Entrepreneurship, 157 (2016)

3. A. Nechaev, D. Ognev, O. Antipina, Advances in Economics, Business and Management Research, 38 (2017)

4. A. Nechaev, Y. Barykina, N. Puchkova, Advances in Economics, Business and Management Research, 38 (2017)

5. A. Nechaev, O. Antipina, Modern Applied Science, 2, 88-96 (2015)

6. A. Cieślik, Ł.Goczek, World Development, 103 (2018)

7. A. Ios, B. Benito, F. Bastida, Australian Journal of Public Administration, 76, 48-64 (2017)

8. A. Morris, H. Neill, Brookings Mountain West Publications, 49 (2014)

9. L. Oulasvirta, A.-V. Anttiroiko, Local Government Studies, 43 (2017)

10. T. Koc, E. Bozdag, European Journal of Operational Research, 257, 559-567 (2017)

11. N. Torugsa, A. Arundel, Research Policy, 46, 900-910 (2017)

12. M. Mukherjee, A. Singh, A. Žaldokas, Journal of Financial Economics, 124, 195-221 (2017)

13. I. Golova, Ekonomika Regiona, 3, 218-232 (2014)

14. A. Milkinis, M. Byrka, Ekonomika, 93, 41-47 (2014)

15. J. Schymik, European Economic Review, 102 (2018)

16. M. Y. Veselovsky, M. A. Izmailova, A. V. Bogoviz, S. V. Lobova, Y. V. Ragulina, Quality - Access to Success, 19(163), 30-36 (2018)

17. B. Stosic, M. Mihic, R. Milutinovic, S. Isljamovic, Technology Analysis and Strategic Management, 29, (2017)

18. M. Y. Veselovsky, M. A. Izmailova, A. V. Bogoviz, S. V. Lobova, A. N. Alekseev, Quality - Access to Success, 19(162), 60-66 (2018)

19. P.-C. Wu, C.-C. Lee, Empirica, 45 (2018)

20. A.B. Fanta, D. Makina, Evidence from South, 85 (2014)

21. A. Kokourix, G. Panagiotis, Journal of Global Entrepreneurship Research, 6, 1-18 (2016) 